\title{
A NEW SECTOR IN TURKISH FOREIGN POLICY: MEDIATION
}

\author{
RAHIME SÜLEYMANOĞLU-KÜRÜM* \\ University of Nottingham
}

\begin{abstract}
Recently, Turkish policy-makers defined Turkey as a 'natural born mediator' and called Turkey's engagement in good offices and mediation part of a new vision in Turkish foreign policy. This was also characterized by the media as a 'new sector' in Turkish foreign policy. Although Turkey's new role was subject to extensive public and media debate, academic literature did not cover it adequately, rather using it as further evidence for their diverse theoretical frameworks. This paper attempts to open up a debate on Turkey's newly adopted role as a mediator and analyzes it from a rational choice institutionalist point of view. It concludes that the EU conditionality has been an instrumental but not a driving factor in Turkey's newly adopted role. It has been used by governments since 1987, as the timeline of this paper indicates, as a way to demonstrate Turkey's adherence to the policy of good neighborly relations and the peaceful settlement of disputes. Even after the EU suspended negotiations, Turkey's active involvement in good offices and mediation missions did not diminish nor did its reduced credibility result in the reversal of the process.
\end{abstract}

Keywords: Turkey, Foreign Policy, good offices, mediation, peaceful settlement of disputes, good neighborly relations, rational choice institutionalism.

TÜRK DIŞ POLITIKASINDA YENİ BIR SEKTÖR: ARABULUCULUK

$\ddot{O Z E T}$

Son zamanlarda, Türkiye'de siyasi karar alıcılar, Türkiye'yi 'doğuştan arabulucu' olarak tanımladılar ve Türkiye'nin arabulucuk ve iyi niyet misyonlarını geniş bir vizyonun bir parçası olarak ilan ettiler. Bu aynı zamanda medyada da Türk dış politikasında 'yeni bir sektör' olarak kabul gördü. Türkiye’nin bu yeni arabuluculuk ve iyi niyet misyonları kamиoyu ve medya tartısmalarına konu olmasına rağmen, akademik literatürde hak ettiği yeri alamadı ve daha ziyade farklı kuramsal çerçeveler için kanıt olarak kullanıldı. Bu makale Türkiye'nin yeni arabuluculuk girişimleri üzerine bir tartışma açarken bu çabaları rasyonel tercih kurumsalcılı̆̆g bakış açısı ile analiz eder. Sonuç olarak bu makale Avrupa Birliği’nin siyasi koşulluluğunun, Türkiye’nin yeni edinilen rolünde araç olarak kullanıldığını, ama

* Rahime Süleymanoğlu-Kürüm is a Ph.D. candidate in the School of Politics and International Relations at University of Nottingham, Law and Social Sciences Building, Nottingham, NG7 2RD, United Kingdom. Email:1dxrs8@nottingham.ac.uk 


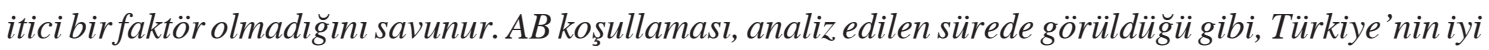
komşuluk ilişkileri ve sorunların barışçıl yollardan çözümüne bağlılığını kanıtlamak için 1987 yılından bu yana hükümetler tarafindan kullanılır olmuştur. Müzakerelerin asklya alınması dahi, Türkiye'nin arabuluculuk ve iyi niyet misyonlarına aktif katılımını azaltmamış, AB'ye olan güvenilirliğin azalması da sürecin tersine dönmesi sonucunu vermemiştir.

Anahtar kelimeler: Türkiye, Dış Politika, iyi niyet, arabuluculuk, anlaşmazlıkların barış̧̨ yollarla çözü̈mlenmesi, iyi komşuluk ilişkileri, rasyonel tercih kurumsalcıllğı.

On November 3, 2009, Sami Kohen, Foreign Affairs Specialist of the daily Milliyet, made an interesting point in his column. He titled his writing as 'A New Sector in Turkish Foreign Policy: Mediation.' Sami Kohen's point is illustrative. He is one of the prominent columnists and his point was timely and wise. Indeed, whether it was named as mediation and good offices or not, Turkey has clearly made a move towards bringing conflicting parties closer to compromise. The recent peaceful moves by Turkey have been subject to extensive media debate. However, academic debate has been limited in this context. Scholars have used good offices and mediation as examples, and as additional evidence for their studies. However, as Sami Kohen noted in his column, Turkey's recent efforts towards building peace in the region need closer attention.

Interestingly enough, this recent change in Turkish foreign policy and its declaration of itself as a 'natural born mediator' became apparent at a time when Turkey was coming closer to the EU. Turkey has been a candidate for membership since December 17, 1999 decision of the Helsinki European Council, followed by the start of accession negotiations on October 3, 2005. In a period when scholars talk extensively about the Europeanization of foreign policy and when 'mediation and good offices' are also extensively used by the EU for conflict prevention purposes, we find it valuable to study whether the EU accession process might have contributed to this self-declaration by Turkey.

Considering the fact that the EU is one of the most powerful economic, political and legal institutions in the world, it is uniquely positioned to positively impact armed conflict situations. Indeed, it actively promotes the principles of conflict prevention and resolution (Herrberg, 2008). The EU's mediation activities range from political and financial support to actual mediation activities. Although mediation as an EU foreign policy tool was adopted with the concept paper by the Council only in 2009, it has long been an established practice, albeit on an ad-hoc basis. The EU is considered a 'multi-track' mediator as it harnesses and co-ordinates the resources and capabilities of States, NGOs, and organizations. ${ }^{(1)}$

By observing the progress of Turkish foreign policy, this paper tries to understand the extent to which EU conditionality has been effective in transforming its adherence to soft power instruments, mainly its involvement in good offices and mediation. Considering both intention and action as the evidence for mediation, this paper tests the effectiveness of EU conditionality in seven phases which allow for variation of the independent variables. It concludes that the preferences of the political parties in government and the degree of their convergence with the EU's demands have been keys for understanding the change in Turkish foreign policy. A favorable domestic capacity has also been significant in turning the policy-makers' intentions into actions and has helped them defend their intentions more decisively. This study posits that domestic capacity and a pro-EU government have been both individually necessary and jointly sufficient conditions for compliance and that the EU's credibility has been of secondary importance. 


\section{MEDIATION AS A NEW SECTOR IN FOREIGN POLICY}

Mediation and good offices are the two methods for the peaceful settlement of disputes identified by the United Nations ${ }^{(2)}$ as well as by the Hague Convention of $1899^{(3)}$ being exclusively 'third party interventions.' In legal terms, good offices and mediation are usually referred to as different mechanisms although they are similar. Both approaches are employed for dispute settlement. ${ }^{(4)}$ In fact, the Hague Conventions of 1899 and 1907 did not differentiate them. Especially in the domestic context, one can find states refusing to identify themselves as mediator. They prefer terms such as 'facilitator,' or 'message carrier.' Sometimes they even avoid taking these positions and they just refer to a 'constructive contribution' in the peace process. This is particularly the case for Turkey. Nevertheless, the literature on mediation does not make such a distinction. In its most apparent form, 'facilitation' is one type of mediation. In general, there are three basic styles in the mediation literature that are relevant to this study. These are 'facilitation,' 'formulation' and 'manipulation' (Bercovitch and Houston, 1996; Princen, 1992; Touval and Zartman, 1985). ${ }^{(5)}$

Mediators try to bring the parties in the conflict to the point where they are willing to talk to each other (Curle, 1986), and try to correct misinformation and provide a channel of communication between the parties without being blinded by such emotions as anger, fear, and suspicion (Curle, 1986; Miall, 1992: 77). When the positions of the parties appear to be rigid, the mediating state can also act as a 'facilitator' during the negotiations. Hence, acting as a 'facilitator' represents a further stage of mediation and it involves the good offices mission. The facilitator listens to the process, asks questions, and seeks to keep the discussion constructive and analytical (Miall, 1992: 74). In order to avoid any confusion, I refer to mediation here in general terms, and I define mediation as any kind of act that is aimed to bring peace between the disputed parties. Within this framework, I include in my definition both 'message carrier,' 'facilitator' and 'constructive contributor to peace.' I sometimes use these terms interchangeably within the merits of this definition.

As defined, this paper uses good offices and mediation as indicators of foreign policy which provide evidence to assess the change. As the change in Turkish foreign policy is a hot debate at the time of writing this paper, good offices and mediation offer an invaluable opportunity to indicate the existence or absence of change. This assumption is derived from Touval's (2003) conceptualization of mediation as part of foreign policy which allows the researcher to bring the debate from a limited perspective of techniques in influencing dynamics to the broader framework of strategic action within the international domestic political systems. Studying mediation as an independent activity simply focuses on how the mediator influences the relationship between the disputants. With the alternative conceptualization of mediation as part of foreign policy, this allows the researcher to evaluate the goals and strategies of states that lead them to mediate in a conflict. From this perspective, the effectiveness of mediation is not limited to ending the conflict, but, in broader terms, it is related to the extent to which the mediator satisfies the foreign policy objectives which motivated it to adopt such a role (Touval, 2003: 92). ${ }^{(6)}$ These foreign policy objectives might be the expansion of the mediator's geographical influence and the advancement of the world order. Thus, this alternative approach allows us to identify mediation as a policy instrument and to test the influence of diverse domestic and international factors that shape the mediating state's behavior.

The hypotheses tested here are that the contributing factors in the development in Turkey's foreign policy sector are its candidacy for full membership in the EU, the continuous pressure from the EU 
to adopt the 'peaceful settlement of disputes' and to adhere to the principles of 'good neighborly relations,' and the recent declaration by the Turkish government of itself as a 'natural born mediator.' Is Turkey adopting such an approach in order to please the EU and to convince its partners that Turkey is adhering to such principles? Or is Turkey adopting such an approach in order to boost its regional importance? Or does Turkey have economic interests to satisfy that motivate it to act as a mediator? Apparently, answering all these questions would be an ambitious project. Here I will offer a more modest one and test whether Turkey's new sector in its foreign policy appeared due to the continuing pressure from the EU.

\section{THEORETICAL FRAMEWORK}

The theoretical assumption to be examined here derives from the 'external incentives model' which is also linked to March and Olsen's (1989) 'logic of consequences.' The assumptions of the model rest on the arguments of rational choice institutionalism. According to the model, states comply with the EU's requirements as a result of a strategic calculation and on their belief that the benefits of compliance exceed the costs. According to this model, the EU level factors are filtered and mediated through domestic level factors. It starts with the identification of 'misfit' between the national level norms on the one hand and the EU level norms on the other hand (Börzel and Risse, 2003; Cowles et al., 2001).

Among the EU level factors, 'conditionality' is the major instrument used by the EU in order to influence applicant states (Hughes et al., 2004: 524). This refers to general or country-specific conditions that the EU formulates through a number of documents and reports, and requires candidate countries to comply with them (Grabbe, 2001, 2003; Schimmelfennig and Sedelmeier, 2004; Smith, 2003;). If the candidates fail to comply, then the EU acts as a 'gate-keeper' in order to embarrass the applicant governments, and prevent them from proceeding to the further stages of integration (Grabbe, 2001: 1021). Nevertheless, apart from the publicly stated preconditions, The EU's Commission has wider leverage in its policy recommendations when the acquis is thin in a policy area. This is referred to as 'informal conditionality' by Hughes et al. (2004: 526), and it is significantly important for foreign policy due to the thinness of the EU in this area. Although it is argued that the lack of clearly formulated demands diminishes the effectiveness of the EU conditionality (Checkel, 2005; Grabbe, 2001, 2003; Hughes et al., 2004; Schimmelfennig, 2004), it is wise to argue that uncertainty leads candidate countries to invent their own ways to convince the EU that they are adopting the requirements set out as conditionality.

Apart from the clarity of demands, and the possibility of informal conditionality, compliance with the EU requirements by applicant states is determined by the size of the rewards (Schimmelfennig and Sedelmeier, 2004). Incentives may be material such as financial aid and market access, or social, such as international recognition, legitimacy, high status or a positive image (Schimmelfennig et al., 2003: 498). Above all, the possibility of full membership is proved to be the strongest reward when this framework is applied to Central and Eastern European States (Schimmelfennig, et al., 2003) and the absence of full membership perspective significantly diminishes the EU's external leverage (Kelley, 2006). The credibility of the EU's incentives is another important factor determining the EU's leverage (Schimmelfennig, 2004; Schimmelfennig and Scholtz, 2008; Schimmelfennig et al., 2003).

Schimmelfennig et al. (2003: 514) highlighted that together with a credible membership promise the low costs of domestic adaptation are defined as individually necessary and jointly sufficient conditions 
for compliance by candidate countries. It is argued that domestic political actors are motivated by a logic of consequences (March and Olsen, 1989) and they follow an instrumentalist approach by trying to maximize their benefits (political or material ones) in complying with the EU conditionality. It is also the domestic adaptation costs that determine the number of veto players who might resist change (Börzel and Risse, 2000; Cowles, et al., 2000; Schimmelfennig et al., 2003; Vachudová, 2001). This in the end determines the reform capacity of a country which depends on the number of veto players and the strength of the political leadership (Héritier and Knill, 2001; Hughes et al., 2004; Radaelli, 2000).

In this paper, it is assumed that the EU's formal conditionality on the peaceful settlement of disputes is also perceived as an 'informal conditionality' by the Turkish policy-makers. Hence, following the practice of the EU foreign policy, Turkish policy makers, who are under constant pressure from the EU, will find ways to demonstrate their adherence to the principles of good neighborly relations and peaceful settlement of disputes. Without doubt, undertaking the mediation and good offices mission is a good way for this and this is what this paper is using as an indicator of foreign policy behavior.

\title{
Hypotheses
}

On the basis of this discussion of the mechanism of conditionality, I put forward hypotheses about the varying effectiveness of the EU's pressure on Turkey with regard to the peaceful settlement of disputes. Following this model, once the EU formulated demands for the peaceful settlement of disputes in the 1989 Commission Opinion (Avis) on Turkey's application, it would remain constant. Hence, the clarity of the EU's demands appeared as early as 1989. From then on, the effectiveness of EU conditionality has depended on the credibility and the adoption costs.

\section{Hypothesis I: The EU conditionality is likely to work when the EU membership perspective is credible.}

The credibility of incentives varies with the size of the incentives. Hence, the more the EU's incentives are close to the full membership reward, the more likely that it will lead to the effectiveness of conditionality.

\begin{abstract}
Hypothesis II: If the EU conditionality is effective, the likelihood of the adoption of the EU's rules depends on the political costs to Turkey in satisfying the EU pressure on the peaceful settlement of disputes. It is assumed that these costs will increase the more the EU conditions negatively affect the security and integrity of the state. Hence, the lower the domestic costs of compliance for Turkey, the more likely conditionality will be effective.
\end{abstract}

In order to test this hypothesis, a number of variables need to be set out. To begin, three kinds of veto players are identified. The preferences of the political parties in government are the first one. If the government is pro-EU, supports Turkey's membership in the EU and adheres to the EU norms of a peaceful settlement of disputes, it is not expected to be a veto player. Next, as Turkish foreign policy is traditionally in the hands of diplomats and the military officials whose power is exerted through the National Security Council (NSC), the autonomy and opinion of these elites become important in order to support or resist change. Lastly, domestic capacity is important. If the country is suffering from 
political instability, economic problems, or facing threats of Islamic fundamentalism or separatism, the response to EU conditionality will be negative.

In line with this background information and the hypotheses derived from the theoretical framework, the test case will be seven phases of Turkish foreign policy which will be indicated by the good offices and mediation roles adopted by Turkey since its application to the EU membership. Because it indicates the desire to change, I take 1987 as the starting date with its application for full membership.

\section{METHODOLOGY}

This section first makes explicit the advantages and pitfalls of the research design, then highlights the considerations made during the data collection process and outlines the problems encountered and the steps taken to overcome these problems. This paper is based on the assumption that good offices and mediation in general are invaluable indicators of foreign policy behavior in which a change can clearly be observed. Such behavior indicates a change towards a 'soft power' approach by shifting to peaceful instruments in conducting foreign affairs and ruling out the use of force. Nevertheless, there are limitations to this approach as the decision of a state to involve itself in mediation might be motivated by a number of other factors, i.e. protecting the economic and security interests of the country. The state undertaking a role as a mediator might give second place to peace, but might be more motivated to achieve peace due to its direct economic or political benefits to the state. These considerations will be highlighted in the empirical section.

As for data collection, a number of factors need to be highlighted. First, both intention and action were considered as evidence for mediation and were then analyzed through different lenses, such as whether the actor offered mediation or was invited to it, whether its role as a mediator was confirmed by other actors, and what procedures were followed in order to start and conduct the mediation and good offices missions. The data was collected mainly from secondary sources such as newspapers, and two methods were followed in order to do that. The first part of the data collection, from 1987 to 1997, was started with the Milliyet newspaper because it has an archive dating back to the 1950s and allows comparison over time. It also has a keyword search which is accessible through the Internet. When the evidence was found in Milliyet, the dates corresponding to that evidence were searched in four other newspapers, Cumhuriyet, Hürriyet, Tercüman and Sabah. These newspapers were selected for pragmatic reasons due to the availability of the data because their archives could be reached in the library of the Turkish Grand National Assembly (TGNA) in Ankara where the microfiche of these newspapers are provided.

For the second period, from 1997 to 2011, all the newspapers are accessible in digital format through a keyword search that can be obtained upon a freedom of information request to the library of the TGNA. There are three difficulties in accessing this data. The first one is because the news was coded into the word document by the staff working in the TGNA library and there were no page numbers as it appeared in the newspaper. With that also, the information can only be collected upon official request. Third, some of the news was not coded when it appeared in two newspapers on the same day. Nevertheless, the system ensures that the news appeared at least once.

Additionally, other data sources such as statements, press releases, governmental documents and other newspapers were also used on a complementary basis in order to trace the process of mediation. 
Governmental papers and press releases from 1997 onwards are also readily available via the Internet and are authentic in the sense that they are official and can be used to make general observations both over time and across different actors. The same documents corresponding to earlier periods can be obtained with the freedom of information request to the Ministry of Foreign Affairs (MFA).

Data has been analyzed carefully in order not to allow the politicization among the newspapers to affect the analysis. For that reason, only facts were traced rather than opinions. Even when using the articles as a data source, the same considerations applied. Considering the fact that mediation was not always used as the term, this thesis does not disregard the fact that different terminologies might imply the same meaning that mediation entails. For that reason, apart from 'mediation,' other terms are also used in order to do the keyword research. These are 'good offices mission,' 'negotiation,' 'good office and dialogue,' 'good sense' and 'peaceful settlement.' Sorting the data through these keywords allows the researcher to confirm that the data is valid and that the relevant information has been added into the datasheet with an assessment of whether the mediation was invited or offered, whether it is accepted or refused, and whether it was conducted or not. Hence, both intention and action are taken into consideration rather than merely the actual action. Finally for referencing, Milliyet is given as the source in order to allow the reader to trace the data.

\section{PHASES OF TURKISH MEDIATION}

\section{Phase I: 1987-1991}

Among the EU level factors, the clarity of the EU's foreign policy has been hard to discern since the EU had a very loose foreign policy coordination within the framework of the European Political Cooperation (EPC); moreover, it was not even applicable to third countries. Nevertheless, as Turkey applied for full membership in 1987, the first Commission Opinion in 1989, generally known as Avis, emphasized the peaceful settlement of disputes and good neighborly relations as areas that need attention. However, the EU did not offer a membership perspective, and therefore it did not have much credibility. Among the domestic level factors, the preferences of the Motherland Party (ANAP) government converged with the EU's preferences in general and it was a pro-EU government as indicated by its application for full membership. Other domestic factors had mixed results. The veto position of the military bureaucracy was low as Özal chose a candidate of his liking to be Chief of Staff, General Necip Torumtay. Nevertheless, the veto position of the civil bureaucracy was high. Both of these veto players were skeptical about the security dimension. Hence, they were against Turkey's mediation in general as they considered it risky. The domestic capacity was low due to both Kurdish terrorism and the poor economic conditions in the country.

Regarding the outcome, Turkey showed an interest in involving itself in good offices and mediation. There were some other favorable factors as well. Due to the fact that Turkey followed a policy of 'active neutrality' towards the Iran-Iraq war, this provided room for Özal to express his intention and grasp the opportunity to offer to mediate between Iran and Iraq. As the conflict expanded to include the US as well, with the same intention and decisiveness, Turkey offered to mediate between Iran and the U.S. However, this could remain an offer only because the US position was completely against Turkey's mediation. While Turkey declared its intention to mediate, the U.S. asked Turkey to become involved in its military operations and criticized Turkey because while Kuwait and other Muslim countries openly supported the U.S., Turkey was asking for 'good faith' although it was a NATO member (Yavuz, 1987). 
Özal also wanted to mediate between Palestine and the U.S. but this plan was soon abandoned because of the harsh criticisms raised by the Foreign Service bureaucracy. Diplomats believed that Turkey had no chance of being successful in such a controversial issue. Turkey's neutrality was already questioned by its acceptance of Waldheim and its recognition of the Palestine Liberation Organization (PLO), thus weakening the relations with the Jewish lobby and Israel. Diplomats believed that not Turkey but the EC could take such a role since Turkey was not in a position to pressure an international conference on Israel. Hence, they believed that such an attempt would have a detrimental effect on Turkey's prestige in the international arena and would damage Turkey's carefully calculated and balanced policies towards the Arab world and the Islamic Middle East (Yalçın, 1988).

These outcomes indicate that Turkey had been interested in playing a role as a mediator and that this had been purely motivated by the preferences of the ruling party, ANAP. Additionally, the effective veto position of the civil bureaucracy, and the US as an external actor were significant. However there was no data to test the military bureaucracy's veto position. These veto positions hampered Turkey putting its intentions into action. An extension of this analysis can clearly identify that economic factors motivated the Özal administration more than peaceful purposes. Considering the fact that the Turkish economy really benefited from 'active neutrality' during Iran-Iraq war, this strategic calculation seems to be quite rational.

President Özal's response to an Armenian invitation to mediate over Nagorno-Karabakh issue by saying that "Armenia should be coerced" indicates that peace was not a priority. While Armenia was open to dialogue and accepted Turkey's role without questioning its neutrality, Özal's declaration led Armenia to start considering Turkey as a party to the conflict (Birand, 1991). Lastly, Özal's decision to involve Turkey in the Gulf War and his emphasis on the economic benefits of being involved was just another confirmation that a peace-making role was not a priority in this time in Turkish foreign policy. Mediation was considered an opportunity for boosting Turkey's interests. If Turkey was motivated by peace-making, it would have offered mediation to Iraq rather than leaving such a role to Norway. Hence, this period clearly indicates the importance of domestic factors alone and without conditionality.

\section{Phase II: 1991-1995}

The EU level variables remained constant. The EU still did not provide a membership perspective, but, rather, continued to pressure Turkey to adhere to the principles of a peaceful settlement of disputes. At the domestic level, there was a change of government. Turkish politics entered an era of coalition governments with the election of the government consisting of the Social Democrat People's Party (Sosyaldemokrat Halkçı Parti-SHP) and the True Path Party (Doğru Yol Partisi - DYP), in short, the SHP-DYP coalition which later turned into the Republican Peoples Party (Cumhuriyet Halk PartisiCHP) and the DYP coalition when the SHP joined the CHP.

Nevertheless, this was a coalition of like-minded parties and they were both supportive of Turkey's integration into the EU. In general they also shared the principles of a peaceful settlement of disputes. Among the other factors, the military bureaucracy held a higher veto position after 1993 when an economic crisis hit the country and inflation reached $100 \%$. This domestic situation was aggravated by the intensifying PKK activity. In such a troubled domestic environment, the military adopted an influential role and its veto position increased. The end of the Cold War created an uncertain environment with newly emerging threats in Turkey's neighborhood. 
When we look at the outcome, Turkey became more active as its foreign policy horizons expanded with the end of the Cold War. This was highlighted by its more active, although hesitant, involvement largely due to the fear of refusal and of being blamed for interfering in the internal affairs of other states. Hence, it did not seek to adopt such a role when the conflict was not between two independent states. A good illustration of this would be Ankara's refusal to mediate between Gorbachev and the Turkic republics, a position which was also shared by the Foreign Service bureaucracy (Bila, 1990). A similar approach was adopted towards Chechnya's invitation which was not confirmed by Russia. Nevertheless, when Turkey's security was at stake, Turkey started to adopt such a role, but it did so by refusing to be named as a 'mediator.' This was apparent in Turkey's approach to the conflict between Georgia and Abkhazia (Sazak, 1994), and between Albania and Macedonia ${ }^{(7)}$ (Doğan, 1995) where in both cases Turkey sought to adopt a 'friendly mission' or 'message carrying' position rather than acting as a 'mediator.' Hence, its peace-making role was not very visible.

This was nowhere more apparent than in Turkey's Iraq policy. When Turkey was invited by Saddam Hussein to mediate between himself and the UN for the removal of the embargo (Art1-Haber, 1995), it was immediately accepted by the Turkish authorities because the Turkish economy suffered from that embargo. Security considerations also became clear when Turkey abandoned its traditional Saddamoriented Iraq policy and offered to mediate between Barzani and Talabani. It displayed an even more uncertain and hesitant approach when it offered to mediate between Barzani and Saddam Hussein. Even though both Kurdish factions accepted this invitation, Turkey withdrew its proposal later on and a Kurdish Summit was held in Dublin under U.S. mediation and Turkey's supervision. Turkey aimed, with the presence of the U.S., to inform Kurdish leaders about the definite necessity of respecting Iraq's territorial integrity and about Ankara's security concerns caused by the PKK's infiltrations into Northern Iraq (Dış-Haberler-Servisi, 1995a; 1995b).

Nonetheless, when the conflict was between two independent states, Turkey was more assertive and did not hesitate to be named as a 'mediator.' A good example of this was Turkey's mediation between Azerbaijan and the Turkic Republics in order to convince them to adopt the Istanbul declaration, supporting the UN-OSCE mission in Karabakh ${ }^{(8)}$ (Çalışkan et al., 1994). Similarly, Turkey hosted a meeting between the Croatian and Bosnian leaders which resulted in an agreement (Batur, 1994; Yinanç, 1994). As the Serbian attacks continued, Turkey offered its 'good offices' mission in order to encourage the idea of a multi-ethnic and multi-lingual federation to empower the Bosnians against the Serbs (Bereket, 1995; Kohen, 1995a). ${ }^{(9)}$ President Süleyman Demirel also offered to mediate between Israel and Palestine and started a shuttle diplomacy for this purpose that involved Egypt also in the process (Bila, 1994; Çınar, 1995). ${ }^{(10)}$ Nevertheless, in most of these cases, there were apparent economic benefits to Turkey. This was clear from Turkey's mediation between Israel and Palestine, which was realized by the establishment of Turkish-Israeli Business Council (Özkaya, 1993). An invitation from the Libyan leader Qaddafi to mediate between him and both the neighboring countries and the West also reminded Turkey of its tardy role and was immediately accepted by Prime Minister Tansu Çiller (Doğan, 1996). However, here too, Turkey tried to collect the money Qaddafi owed to Turkey, to end his support to PKK terrorism and stop the money transfers to the mosques which the Islamic Welfare party had been receiving.

The results indicate that Turkey was not motivated by resolving international conflicts primarily, but by maximizing its economic and security interests. Even at times when it was motivated by peace-making interests, such as between Israel and Palestine, it also tried to enhance its economic interests. In the overall sense, it adopted a hesitant approach to mediation and tried to avoid the blame of interfering 
in the internal affairs of another state. When there were no clear benefits to Turkey, mediation offers faced resistance from the Foreign Service bureaucracy fearing that it might have a detrimental effect on Turkey's interests. Hence, the EU had no visibility; only domestic factors shaped Turkish foreign policy during this time.

\section{Phase III: 1995-1997}

Among the EU level variables, the EU's credibility increased slightly with the establishment of a customs union, but none of the documents promised full membership to Turkey as it desired. Despite its low credibility, the EU continued its political conditionality with regard to the peaceful settlement of disputes. Even though the EU referred to the Cyprus dispute and relations with Greece, this was combined with an informal conditionality on other matters. Hence, the size and credibility of the incentives were low. The domestic level variables highlighted a tension between the coalition partners inside Turkey. In particular, the True Path Party (Doğru Yol Partisi -DYP) and the Welfare Party (Refah Partisi-RP) coalition was marked with differences in opinion due to their different ideological orientations. Although the coalition program supported Turkey's membership, it was without emphasis. Other domestic problems such as intense PKK terrorism, economic problems and the threat of Islamic fundamentalism were prevalent as well. In such a troubled environment, the military had a strong veto position.

As for the outcome, Turkey continued with its hesitant approach in an even more visible way. It declared its intention to mediate only when its security was under threat; it avoided doing so alone, and tried to involve other countries as well. Turkey's approach in supporting a ceasefire among the Kurdish leaders was a good example when it sought the U.S. involvement as before (Kohen, 1996). Since it did not produce any progress, Turkey invited Iran to take a joint action in order to bring the Kurdish leaders into an agreement (Güven, 1996). Turkey also deafened its ears to Saddam Hussein's invitations to mediate between Iraq and Israel, but rather offered to mediate between the U.S. and Iraq in order to prevent the possibility of a military operation by the U.S. At the same time Iraq also sent some signals asking for Turkey's mediation (Emirlioğlu, 1997). All these indicated a strong focus on a security approach. Decision-makers preferred not to adopt the sensitive roles which they considered detrimental to Turkey's security. This was also apparent from Turkey's refusal to act as a mediator in the peace process, but simply passed messages, without naming itself as such, even though improved relations with Israel gave Turkey a better chance to involve itself as a mediator (Bila, 1996; Yazaroğlu, 1997).

Turkey also refused to take such a role in Afghanistan in order to stop the Islamic fundamentalism of the Taliban regime. The Foreign Service bureaucrats believed that Turkey's prestige would be hurt since it did not have any chance of being successful while there were other strong actors in the region (Çakırözler, 1996; Kohen, 1996). Referring to the territorial integrity of Afghanistan, Çiller declared her willingness to host a meeting for peace talks on Afghanistan if it were under UN auspices (Yinanç, 1996). If collective action was to be taken, Turkey declared its willingness to engage in shuttle diplomacy in order to convince the conflicting parties to sit at the negotiating table (Report, 1997). The same hesitant approach persisted. Turkey missed an important opportunity by deafening its ears to calls for mediation from the Chechen leader Dudayev and from his widowed wife Alla Dudayeva, knowing that it would not be accepted by Russia. Turkey was also concerned that its mediation would mean the abandonment of the Turkish policy which recognized the Chechen problems as an 'internal 
affair,' although acceptance of such a role by the Kremlin would confirm Turkey's role as regional player (Başlamış, 1996).

The results indicate that Turkey was not influenced by the EU conditionality whatsoever. Security considerations clearly prevailed and the positions of the Foreign Service bureaucracy did not leave any room for elected representatives to engage in such a role. The domestic situation was aggravated by PKK terrorism, and added to this the Syrian support of the PKK and the conflict over Kardak/Imia islets pushed Turkey to become an inward-looking country. Turkey was slowly missing the golden opportunity created by the dissolution of the Eastern Bloc and was stepping back while Russia and Iran were taking important steps in Central Asia and the Caucasus. Other problems included the slow process in the formation of the government after the 24th of December elections that took more than six months. Due to the fragile domestic environment, important international problems that required urgent attention failed short of the agenda. Turkey was almost pushed out of the region with the steps taken by Russia and Iran. In terms of regional substance also, Turkey pulled back from the Balkans and did not involve itself as a mediator. Security problems alone dominated the agenda.

\section{Phase IV: 1997-1999}

Among the EU level factors, the EU continued to formulate clear demands. However, the credibility of the incentives declined with the Luxembourg European Council's exclusion of Turkey as a candidate country. At the domestic level, coalition governments serving during this period ${ }^{(11)}$ had a higher degree of convergence with the EU. All the parties serving in the government were supportive of Turkey's membership with the EU. However, domestic capacity continued to be low due to the continuing intensity of PKK terrorism. On the other hand, the veto position of the civil bureaucracy and the military bureaucracy continued to be high.

As for the outcome, Turkey's mediation attempts were motivated by protecting its security by trying to stop the regional conflicts and achieving peace. This was apparent in Turkey's willingness to mediate between the U.S. and Iraq in order to convince Saddam Hussein to comply with the international demands so as to stop an American invasion of Iraq. Such an intervention would clearly have detrimental effects on the Turkish economy as the first Gulf War demonstrated. Achieving peace was clearly of secondary importance. Turkey was decisive in ending the conflict by offering its mediation. When the reactions became apparent from the U.S., Turkey called its role not 'mediation' but 'facilitation' and a good offices mission. In reality, Foreign Minister İsmail Cem was no more than a 'message carrier.' He aimed to convince Iraq to comply with the UN decisions (Çakıroğlu, 1998). Due to the concerns over the consequences of the war on Turkey, all the domestic actors supported Turkey's mediation efforts in consultation with the regional countries such as Iran, Egypt, and Jordan as well as the UN, rather than taking a unilateral approach (Kohen, 1998). However, there was an extreme concern by the

policy makers regarding Turkey's role in visiting Saddam Hussein. This concern became clear when the Prime Minister declared that İsmail Cem took this initiative on behalf of his party and that as the Foreign Minister he did not represent the government (Report, 1998).

Turkey was also invited by Arafat to mediate between Palestine and Israel: but İsmail Cem called attention to the U.S. dimension and to Israel's internal dynamics. It was clear that Turkey needed the U.S. to confirm such a role for Turkey (Yılmaz and Yazaroğlu, 1998). However, İsmail Cem wanted to include Jordan and Egypt in the peace process and take a collective initiative. He offered a regional cooperation and security forum similar to OSCE, as a mechanism (Yinanç and Yazaroğlu, 1998). 
In other cases, Turkish mediation involved only the Caucasus which included mediation between Turkmenistan and Azerbaijan regarding the natural gas and oil pipeline issues. However, this role was also far from being motivated by either a peace plan or normative considerations. Contrary to its ambivalent position in the Middle East, the U.S. was entirely supportive of this mediation as it wanted to push Iran away from the game. On the other hand, Turkey was trying to mediate between Iran and the U.S. Turkey had obvious economic benefits for involving itself in such mediation. In fact, as a result, Turkey managed to sign an agreement with Chernomyrdin. Turkey also undertook consultations with Kazakhstan, Turkmenistan, Azerbaijan, and Iran and involved the U.S. in the plans that managed to bring the process to a stage of feasibility studies on an energy agreement (Bila, 1999; Doğan, 1998).

The results indicate that Turkey continued to balance its economy and security. Although peacemaking was included in the intentions of the policy makers, the low domestic capacity due to high security risks required it to give priority to ensuring its security. Nevertheless, one can also highlight the fact that Turkey was influenced by the reduced credibility of the EU membership perspective due to its exclusion as a candidate in Luxembourg European Council. This was quite visible compared to the earlier period. Despite the fact that the government's ideology was closer to the EU norms, Turkey was less involved in mediation. On the other hand, domestic constraints and the veto position of the civil bureaucracy were very effective because Turkey was involved in mediation only to ensure its security and economic interests.

\section{Phase V: 1999-2002}

During this process, there was a significant change in the EU level variables. Turkey was declared a candidate country in the Helsinki European Council in 1999 which made the EU membership perspective credible for the first time. The EU also continued to formulate demands, albeit clearly aimed at the peaceful settlement of disputes and good neighborly relations. At the domestic level, there was a change of government, and the coming into power of the ANASOL-M government, a coalition of ANAP-DSP-MHP parties that had a highly converging ideology with the EU. Despite the fact that the MHP was a nationalist party, they did not deviate from the general pattern of supporting the EU. As for the domestic capacity, the PKK terrorism was minimized with the arrest of its leader Abdullah Öcalan. On the other hand, an economic crises hit the country badly during this whole phase.

As for the outcome, the peace-making role started to appear slightly as can be observed by Foreign Minister İsmail Cem's self-declared 'facilitator' role in the Middle East peace process by partially abandoning his fears. Again, there was controversial domestic debate on the role, and the title 'facilitator' seems to be a compromise in order to avoid using 'mediator.' It was referred to as a 'constructive contributor' for achieving peace in order to avoid challenging the Camp David process ${ }^{(12)}$ (Report, 2000a). However, Foreign Minister İsmail Cem acted more decisively by warning Arafat not to hinder the peace process and by declaring his good faith by allowing Jewish worship in the Harem El-Sharif (Yinanç, 2000b). İsmail Cem acted constructively and declared that he wanted to bring new ideas based on the experiences of ruling Jerusalem for four hundred years. In order to avoid hindering the balanced relations with the Middle Eastern neighbors, Cem acted cautiously in his statements that could have had a negative influence in the Arabic and Islamic world, in the U.S. and Christian world and in Israel. He also sought to coordinate Turkey's policies and to consult the U.S. as well as other regional countries (Kohen, 2000; Payzın, 2000; Yinanç, 2000a). 
İsmail Cem also wanted to initiate a peace committee, also invited by Israel, to end the violence. However, Prime Minister Ecevit did not want to be involved directly, mostly due to the ongoing American initiatives and the belief that Turkey's prestige would be hurt if it was not successful. Therefore, Ecevit suggested that peace committee should involve volunteers from both sides at the civil society level; this could also create an environment for dialogue between the parties rather than Turkey's sitting in at the official level (Y1lmaz, 2001). These efforts paid off later and President Demirel was invited by American Foreign Minister Albright to participate in the mediation committee which was interpreted as a confirmation of Turkey's weight (Report, 2000b). During his involvement in the Middle East Examination Committee, Demirel sought further initiatives such as hosting the second meeting of the committee and the participation of two Turkish citizens on the expert committee that would be sent to the region (Report, 2000c).

With regard to the Caucasus, President Demirel started to mediate between Georgia and Azerbaijan during his visit to Tbilisi over the conflict regarding the Baku-Ceyhan pipeline. Turkey had obvious gains from this mediation as Demirel also met Clinton's advisor and informed him about the importance of the pipeline issue for Turkey. With regard to the dispute between Azerbaijan and Armenia, a Caucasus Stability Pact was initiated by Turkey but its active involvement was limited by the lack of diplomatic relations with Armenia (Eralp, 2001). Later on, Foreign Minister İsmail Cem made a step forward and offered for Turkey to mediate negotiations between Azerbaijan and Armenia. However, the Armenian Foreign Ministry immediately rejected Turkey's mediation on account of Turkey constituting a party to the conflict. Armenia considered the lack of diplomatic relations between the two countries as an obstacle to such a role (Eralp, 2001). It is important to note that Demirel's visit to Georgia after visiting Azerbaijan also signaled that Turkey put a value on Georgian territorial integrity which was under threat from Russia. Additionally, Turkey was also involved in passing messages from Pakistan who sought to start dialogue, to India during his visit to Pakistan and India (Yilmaz, 2000).

Overall, the results indicated that Turkey continued to follow an isolated approach with the exception of a more active involvement in the Middle East peace process. Hence, the EU's increasing credibility did not translate into a more active involvement by Turkey in the peaceful activities in its neighborhood. This clearly indicates the importance of domestic factors such as low domestic capacity due to economic crises and the perception of a high threat from PKK terrorism. Perceptions of Prime Minister Ecevit and the Foreign Service bureaucracy prevailed. Hence, when Turkey did not gain any direct benefits from mediation, it did not seek such a role.

\section{Phase VI: 2002-2006}

In this phase, the EU level factors remained constant. The EU continued to formulate clear demands for peaceful settlement of disputes. The size and credibility of the incentives remained constant. With the Copenhagen European Council decision in 2002, the possibility of opening accession negotiations appeared. Hence, the EU kept the process alive despite negative statements from Sarkozy, and public opinion supported the EU membership. At the domestic level, the election of the AKP (Justice and Development Party) to the government highlighted a dramatic change. Despite the new AKP government being a moderate Islamic one, its support for Turkey's membership in the EU was the highest among all the governments since the periods I have examined here. Another dramatic change was perhaps the strength of the government. Although the AKP got only $34 \%$ of the votes, due to the characteristics of the electoral system, it managed to get $66 \%$ of the seats in the Parliament. Therefore, 
the government was able to take decisions fairly quickly without being vulnerable to the opinions of other parties. Simultaneously, domestic capacity improved considerably. The IMF-imposed economic program in 2001 by the ANASOL-M government started to yield fruits and the economy stabilized. PKK terrorism was also minimal.

As for the outcome, the immediate benefits appeared in Turkish foreign policy. It broke its isolationist, inward looking policy by actively becoming involved in the resolution of international conflicts. This role was clearly integrated into the foreign policy goals when it declared its role as a "natural born mediator' between the Muslim and non-Muslim world due to its culture and identity. With the progress in the EU membership perspective, Turkey gained self-confidence as its ties with the EU rendered Turkey more acceptable in the region. The chief foreign policy advisor took an active interest in promoting the EU's policies in which helping in the resolution of the conflicts in the region was one of them. Nevertheless, Turkey's role as a mediator or facilitator was not greeted with the same interest in all regions.

In the Middle East, a number of steps were taken. Building on İsmail Cem's initiative of involving regional countries in order to prevent the possibility of a war between the U.S. and Iraq, a meeting of Iraqi neighbors started in 2003. Additionally, Turkey showed a decisive role in reducing tension between Iran and Syria (Önal, 2005; Report, 2003a). Despite the fact that Turkish public opinion was pro-Palestinian and other Arab and Muslim countries were against Israel, Turkey insisted in adopting a political role in resolving the Israeli-Palestinian dispute (Erdoğan, 2005; Öke, 2004). Neither the absence of a request from the parties (Report, 2003b) nor its exclusion from the Middle East Peace Conference held in London (Report, 2005) discouraged Turkey. Turkey's role was considered only in terms of infrastructure and logistics, rather than as active participation in the political process. Despite these unfavorable conditions, Turkey started to take initiatives at the Track II level ${ }^{(13)}$ by holding an 'economic summit' for the reconstruction of Gaza, and it included the Union of Chambers and Commodity Exchanges of Turkey (Türkiye Odalar ve Borsalar Birliği -TOBB) in the process (Çakırözer, 2005). Within this context, two meetings were held by Israeli and Palestinian businessmen, which were considered as an important peaceful initiative (İdiz, 2005). Additionally, Turkey made a direct investment in the Erez Industrial Zone and set up a hotline to Palestine in order to contribute to the peace process (Report, 2005a).

Turkey's decisiveness in involving itself in the political process became particularly apparent when it invited Hamas representatives as soon as Hamas won the elections. After consultations with Pakistan and the Organization of Islamic Conference (OIC), it recommended that its leaders put down their arms and work with El-Fetih. Despite being criticized for inviting Hamas, Erdoğan spoke to European leaders arguing that ignoring dialogue with Hamas was not the right thing to do because Hamas was chosen by the Palestinian people and its opinion had to be respected. In a similar vein, Turkey declared its intention to 'facilitate' talks between Israel and Syria (Bayramoğlu, 2004) which was crucial for making Turkey's active foreign policy possible.

Turkey also adopted a diplomatic initiative and mediated between Pakistan and Israel for the establishment of diplomatic relations between the two countries ${ }^{(14)}$ (Report, 2005d). Optimism also came from Caucasus following the statement by Abdullah Gül after his visit to Azerbaijan reporting the plans for a trilateral summit between Turkey, Armenia and Azerbaijan in order to contribute to the settlement of the 12-year-old conflict over Karabakh. But at the same time, Turkey maintained its traditional policy of not opening its border to Armenia prior to the settlement of the conflict (Report, 
2004a). However, the plans were later withdrawn when the Armenian Foreign Minister Oskanyan declared Turkey a party to the conflict and argued that its mediation could be effective only if Turkey stopped putting preconditions for the establishment of diplomatic relations (Report, 2005c).

One contradiction was that Turkey did not treat all the regions in the same way. For instance, despite the calls from the civil society, it did not intend to mediate between Chechnya and Russia. It was silent about the Orange Revolution in the Ukraine and the conflict between South Ossetia and Abkhazia despite the ties Turkey had in these regions and despite an open invitation from the Georgian Head of State Saakashvili (Balbay, 2004). On the other hand, when a dispute erupted between Russia and the Ukraine over natural gas, Ankara sought to activate the Black Sea Economic Cooperation (BSEC) in order to contribute to peace. However, there could be little doubt that Turkey's main concern was protecting its economic interests due to its heavy dependency on the Russian gas which was transmitted through the Ukraine (Sarıkaya, 2006).

The results indicate that there was a dramatic change in the intentions of the leaders, not just in their interest in boosting Turkey's economic and security interests but also in contributing to world peace. The actors were clearly motivated also by normative considerations. It became clear that changes in the domestic level variables, namely the low autonomy of the veto players and high domestic capacity had been significant. This period made it clear that credibility alone was not the factor that drove the change, as credibility in the earlier period did not translate into such a dramatic change in the intentions declared. Likewise it is also important to emphasize that the Turkish policy-makers justified their intentions by relying on European norms.

\section{Phase VII: 2006-2010}

During this last phase, there was a change in the EU level factors due to the suspension of negotiations in eight chapters by a decision of the European Commission and the subsequent blocking of five chapters by France and six chapters by the Greek Cypriot administration. The credibility of the incentives was reduced even though the EU continued to pressure Turkey in the same way regarding the peaceful settlement of disputes. At the domestic level, the AKP was re-elected for its second term in the general elections in 2007. Other domestic factors remained constant as well, with the exception of the 2009 global financial crisis which did not affect Turkey as much as it affected Europe and the U.S. The military and the Foreign Service bureaucracy remained silent due to their low veto position. Hence, the domestic factors were largely favorable.

As for the outcome, Turkey continued to promote itself as a peace builder in a number of regions, e.g. Afghanistan, the Caucasus, the Middle East, and the Balkans. Contributing to 'peace' was declared the primary aim, together with impartiality, tolerance and mutual respect. Davutoğlu declared that the mediation and good offices missions that Turkey undertook were part of a vision rather than ordinary policy choices which required Turkey to continue the same approach even in the absence of a conflict (Kohen, 2011). Sami Kohen's point that he made in 2009 also indicated that 'mediation' became a 'sector' in Turkish foreign policy. Among the most important mediation incidents were the ones between Syria and Israel, Pakistan and Afghanistan, Iraq and Syria, as well as between certain religious and ethnic groups in Iraq and Lebanon. In the Balkans as well, Turkey tried to reconcile Croatia and Bosnia-Herzegovina with Serbia. Turkey continued to host regular meetings on Iraq and provided substantial humanitarian aid to Palestinians when the conflict broke out between Hamas and Israel 
over Gaza. It also immediately announced its intention of mediating after a series of consultations with the UN Secretary-General, the U.S., the Russian President and the UK Prime Minister.

It also actively took the role as a 'facilitator' between Israel and Lebanon following a large scale military operation by Israel against the Hezbollah movement in Lebanon. It deployed its peacekeeping troops under the aegis of the UN, and Turkey's appropriate proposals were accepted with satisfaction by the UN, the Lebanese government, and the pro-Western Arab countries, Egypt, Saudi Arabia, as well as the EU. Additionally, it hosted a meeting of the EU High Representative for Common Foreign and Security Policy (CFSP), Mr. Solana, and the Chief Negotiator of Iran's nuclear program, Mr. Laricani, in Ankara. Perhaps, the most obvious initiative was its initiation of peace talks between Syria and Israel after eight years in 2008 in a meeting which Turkey hosted and acted as a 'facilitator.' While Ankara's reaction to Israel's offensive in Gaza led Israel to question its role, both the U.S. and the EU still wanted to bring the parties to the negotiation table with Turkey's mediation. It also intended to mediate between Hamas and El-Fetih in 2009 due to the long lack of progress in direct negotiations between the parties.

A similar role was also adopted in South Asia when Turkey initiated peace talks between Pakistani President Pervez Musharraf and Afghan President Hamid Karzai beginning in 2007. This mediation too was offered after consultations with the UN General Assembly and the Secretary General. Also at the Track II level, Turkey invited the representatives of the business sector within the framework of the Istanbul forum founded by the TOBB to meet with its equivalent bodies from Afghanistan and Pakistan. Turkey also wanted to include the Taliban in the political process in Afghanistan and declared its intention to mediate between Afghanistan and the Taliban.

In the Caucasus, when the conflict broke out in Ossetia Turkey immediately declared its objective of mediating, and its policy-makers refrained from making statements that could jeopardize Turkey's role as such. Turkey believed that conflicts could only be resolved by peaceful means; additionally it initiated the Caspian Stability and Cooperation Platform in 2008 in order to contribute to the peace. To that end, it started to mediate between Baku and Ashgabat over a problem with the gas line and started a 'good offices mission' to help resolve a deep-seated dispute between Azerbaijan and Turkmenistan on the status of the Caspian Sea. A similar role was adopted in the Balkans between Bosnia-Herzegovina and Serbia on the one hand and Croatia and Bosnia-Herzegovina on the other hand; Turkey initiated Consultation Summits with these countries on regional matters.

The results indicate that although the credibility of the full membership reward by the EU declined considerably, Turkey decisively continued to adopt a mediator role in its region. Therefore, it is largely believed that with these initiatives, Turkey tried to improve its position in the negotiations on its membership in the EU. Nevertheless, it is important to emphasize that Turkey also served its best interests during these negotiations. Its mediation between Turkmenistan and Azerbaijan was clearly motivated by clearing the way for Turkmen gas to arrive in Turkey via the same route used in the transfer of gas from the Azeri Shah Deniz field. Its continuing mediation between the Ukraine and Russia can also be added to this. Additionally, Turkey's role in the Balkans can be considered as a first step toward improving her relations with the EU. This period demonstrated that domestic factors have been more significant than the EU's credibility. 


\section{FINDINGS}

The evolution of the intention and action of Turkey's mediation and good offices mission clearly shows that a credible EU membership perspective has been instrumental in transforming Turkey. But domestic factors have proved to be more significant. The table below provides a summary of the hypotheses and outcomes. It is clear that even in the absence of a clearly formulated EU conditionality, which makes the EU membership perspective not credible, the position of the ruling government's ideology that converged with the EU has been sufficient to motivate Turkish leaders to take the initiative to mediate conflicts. Even when the demands became credible, Turkish leaders displayed hesitation both in the geographical sense and also at the substantive level. This is to say, Turkish leaders were extremely sensitive not to contradict the principle of non-interference in the internal affairs of another state, and involved themselves in mediation only when it would enhance their country's security and economic interests. Phase III has demonstrated that government's position has also been significant, but, with the low credibility of the EU's incentives, it was not sufficient. Phase IV, and Phase VII also demonstrated that even without conditionality, the Turkish leaders have been interested in adopting a peace-making role using mediation and good offices. Phase VII was particularly revealing as diminishing credibility did not reduce Turkey's role nor was the process reversed. It was even further enhanced by an active involvement of Turkey, as opposed to the hesitant approach that could not go beyond declaration of intention, as it had been the case in the previous periods. In this respect, the last phase indicated that a pro-EU government together with a favorable domestic environment was individually necessary and jointly sufficient for compliance with the EU conditionality.

Table 1

Summary of Hypotheses

\begin{tabular}{lccccccc}
\hline Phases & \multicolumn{2}{c}{ EU-Level } & \multicolumn{2}{l}{ Domestic Level } & & Outcome \\
\hline & Clarity & Credibility & $\underline{\text { Govt }}$ & $\underline{\text { Veto }}$ & $\underline{\text { Costs }}$ & $\underline{\text { Cap }}$ & \\
1987-1991 & no & no & high & high & high & low & intention \\
$1991-1995$ & yes & no & high & high & high & low & hesitation \\
$1995-1997$ & yes & low & low & high & high & low & hesitation \\
$1997-1999$ & yes & no & high & high & high & low & hesitation \\
$1999-2002$ & yes & high & high & high & high & low & hesitation \\
$2002-2006$ & yes & high & high & low & low & high & intention \\
$2006-2010$ & yes & low & high & low & low & high & action \\
\hline
\end{tabular}

\section{CONCLUSION}

In sum, Sami Kohen's point that Turkey adopted a new 'sector' in its foreign policy is empirically justified. Even though Turkish mediation was not only motivated primarily by achieving peace, there is significant evidence to claim that in fact a new instrument appeared in Turkish foreign policy which can be actively used. Nevertheless, it is crucially important to stress that it was used as a 'sector,' but it is not really new since we traced the intentions of the Turkish policy makers beginning in 1987 . It clearly demonstrates that since the Özal period, Turkey has wanted to play an active role in its neighborhood and has considered the good offices and mediation mission important instruments to 
achieve that objective. Nevertheless, for some years neither domestic nor international factors were conducive to this. The end of the Cold War provided a significant opportunity, but Turkey entered into a period of coalition governments and was suffering from threats of Islamic fundamentalism and Kurdish terrorism. Added to these were continuing economic problems which were further reinforced by persistent political instability. All these factors forced Turkish policy-makers to take 'one step ahead and one step back' and Turkey displayed a hesitant behavior in declaring its desire to act as a mediator. Hence policy makers struggled between protecting security and furthering economic interests which did not allow them to take a more active role.

The Foreign Service bureaucracy has also been significant in such a troubled environment because its veto card was used on several occasions. The diplomats believed that mediation was too risky given that Turkey already had significant problems and did not need anything more. They were quite skeptical about Turkey's mediation role because they believed that the parties in the conflict might start to consider Turkey a party to the conflict as the case of Armenia demonstrates. The Turkish policy-makers were able to put the long declared intentions into action only after its domestic capacity improved, thus giving the policy-makers self-confidence. This happened largely when the economic situation improved and Kurdish terrorism was minimized. The presence of a strong government holding the majority of the seats in the Parliament also contributed to this to a great extent. Within such an environment, EU membership perspective became only instrumental but did not contribute greatly to the change in itself.

\section{NOTES}

1. For more information on the EU's mediation, see Communication from the General Secretariat of the Council to COREPER/Council, on the "Concept on Strengthening EU Mediation and Dialogue Capacities," available [online] at: http://www.eupm.org/FCKeditor/Images/File/CoEU\%20\%20 Strengthening\%20EU\%20Mediation\%20-\%2015779-09.pdf, accessed on 18/03/2011.

2. One of the purposes of the United Nations, set out in Article 1 (1) of the Charter requires "all the members to refrain in their international relations which might lead to breach of the peace."

3. See Article 4 of the Hague Convention on the Pacific Settlement of Disputes.

4. Collier and Lowe (1999: 27) explain that "the distinction between mediation and good offices is sometimes taken to be that whereas in the former the mediator takes active steps of his or its own, good offices consists of an action taken by a third party, to bring out, or initiate, or cause to be continued, negotiations, without the third party actively participating in the discussions of the dispute."

5. Bercovitch and Gartner (2006) use slightly different terminology for these styles, classifying them as communication, facilitation, procedural, and directive strategies. Each of these styles entails a different type of mediator involvement and dictates the parameters of mediator behavior.

6. This assumption does not mean that mediating states disregard principles for effective mediation, but rather that effectiveness is usually a secondary consideration, subordinate to the mediating state's primary domestic and foreign policy concerns (Touval, 2003: 94). 
7. The relations between Albania and Macedonia were thorny. Twenty-three percent of the Macedonian population is Albanian, and ethnically Macedonia is a mosaic. Their constitution defines all of them as Macedonian and states that Macedonian nationals include them. However, Albanians do not accept this and they want autonomy. Albania is also very sensitive about the rights of Albanians living in Macedonia. Therefore, the leadership of the two countries came very close to conflict. Demirel's visit therefore was timely.

8. Kazakhstan and Uzbekistan did not want to adopt the UN and OSCE decisions in Karabakh, and Kazakhstan even refrained from declaring Armenia as the 'aggressor state.'

9. Turkey did not offer to mediate between Bosnia and Serbs as it did not have an ongoing dialogue with Milosevic or Karadzic. Turkey merely mobilized the international community in order to act in Bosnia (Kohen, 1995b; Report, 1995).

10. In support of Demirel's initiatives, Tansu Çiller also paid a historic visit to Israel and Palestine as the first team at the Prime Ministerial level to visit Palestine (Çınar, 1995)

11. There were two Coalition governments in this period. The first one was comprised of the True Path Party (Doğru Yol Partisi-DSP), the Democratic Turkey Party (Demokratik Türkiye PartisiDTP) and the Motherland Party (Anavatan Partisi - ANAP). The second coalition government was comprised of the DYP, the Democratic Left Party (Demokratik Sol Parti - DSP) and the ANAP.

12. According to the Camp David Accords which started in 2000, the US was defined as the sole mediator in the Middle East Peace process.

13. Track II level refers to the involvement of non-state actors in international peace mediation. The EU recognizes the importance of Track II actors in mediation. For further information about EU mediation styles, see Herrberg (2008).

14. This is in fact a very important achievement because Israel's political relations with the Islamic world were limited to Turkey, Jordan, Egypt and Mauritania and its trade relations to Morocco, Tunisia and Qatar. As Prime Minister, Erdoğan played the role of mediator; the meeting was hosted by Bağış and Aydın on behalf of Foreign Minister Abdullah Gül.

\section{REFERENCES}

Art1-Haber. (1995). Milliyet, (October 26): 17.

Balbay, M. (2004). “Saakaşvili’nin Tehlikeli Oyunu (Saakashvili’s Dangerous Game)," Cumhuriyet, (August 26).

Başlamış, C. (1996). “Türkiye Kan Kaybediyor (Turkey is Losing Blood),” Milliyet, (May 14): 19.

Batur, N. (1994). "Diplomasi Koridoru: Çiller'le İki Saat (Diplomacy Corridor: Two Hours with Çiller)," Milliyet, (February 4): 23. 
Bayramoğlu, A. (2004). "ABD Gezisinin Asli Amaçları (The Real Objectives of the Visit to the U.S.)," Yeni Şafak, (January 28).

Bercovitch, J. and Scott S.G. (2006). "Is There Method in the Madness of Mediation? Some Lessons for Mediators from Quantitative Studies of Mediation," International Interactions, 32(4): 329-354.

Bercovitch, J., and Houston, A. (1996). "The Study of International Mediation: Theoretical Issues and Empirical Evidence,” in J. Bercovitch (ed.), Resolving International Conflicts: 11-35. Boulder, CO: Lynne Reinner.

Bereket, M. (1995). “Bosna'da Dönüm Noktas1 (Turning Point in Bosnia),” Milliyet, (May 20): 17.

Bila, F. (1990)." Sovyetler'le 'Arabuluculuk' Önerisi (Mediation Offer to the Soviets)." Milliyet, (March 5): 9.

------, (1994). "Davos Notları: Harem'de Filistin Anlaşması (Davos Notes: Palestine Agreement in Davos on al-Aqsa)," Milliyet, (February 1): 11.

------, (1996). “Kulis: Demirel'in Barış Seferi (The Backstage: Demirel's Peace Journey),” Milliyet, (March 12):12.

------, (1999). “Gazda Sicak Saatler (Hot Times in Gas),” Milliyet, (October 8): 1.

Birand, M.A. (1991). “Türkiye Arabulucu Olsun (Turkey should be Mediator),” Milliyet, (October 4): 15.

Börzel, T.A. and Risse, T. (2000). "When Europe Hits Home: Europeanization and Domestic Change," European Integration online Papers (EIoP), 4(15). Available [online] at: http://eiop.or.at/eiop/texte/2000-015a.htm.

Börzel, T. and Risse, T. (2003). "Conceptualizing the Domestic Impact of Europe," in K. Featherstone, and C.M. Radaelli (eds.), The Politics of Europeanization: 57-80. Oxford: Oxford University Press.

Collier, J. and Lowe, V. (1999). The Settlement of Disputes in International Law: Institutions and Procedures. New York: Oxford University Press.

Çakıroğlu, P. (1998). “Enflasyonla Mücadele Etkilenebilir (The Fight Against Inflation can be Influenced)," Milliyet, (February 2): 9.

Çakırözler, U. (1996). "Hoca Afganistan İçin Devrede (The Hodja is in Charge for Afghanistan," Milliyet, (October 17): 18.

-----, (2005). “Yeter ki İsrail İstesin! (If Israel Wants!),” Milliyet, (May 3).

Çalışkan, F., Özkaya, E., and Yılmaz, İ. (1994). "Rusya’ya Karşı Ortak Tavır (Common Position on Russia)," Milliyet, (October 20): 19. 
Checkel, J.T. (2005). "International Institutions and Socialization in Europe: Introduction and Framework," International Organization, (Fall): 59.

Çınar, Y. (1995). “Çiller’in Davos Pazarlı̆̆ (Çiller's Davos Bargaining),” Milliyet, (January 30): 22.

Cowles, M.G., Caporaso, J., and Risse, T. (2001). "Europeanization and Domestic Change: Introduction," in M.G. Cowles, J. Caporaso, and T. Risse (eds.), Transforming Europe: 1-20. Ithaca and London: Cornell University Press.

Curle, A. (1986). In the Middle: Non-Official Mediation in Violent Situations. New York: Berg.

Dış-Haberler-Servisi. (1995a). "K. Irak Ankara'yı Dinledi (Northern Iraq Listened to Ankara)," Milliyet, (August 12): 19.

-----, (1995b). "PKK'dan Kuzey Irak Tehdidi (Northern Iraq Threat from the PKK)," Milliyet, (August 19): 17.

Doğan, Y. (1995). “Türkiye Sözünde Durmadı (Turkey did not Keep its Promise),” Milliyet, (April 10): 15 .

------, (1995). “Günlük: Demirel Arabulucu (Diary: Demirel is Mediator),” Milliyet, (July 13): 11.

-----, (1996). “Kaddafi: “ABD, İstanbul'u Yunanlı’ya Verir” (Qaddafi: “The US might give Istanbul to Greece”)," Milliyet, (October 8): 15.

-----, (1998). “Ha Boru Hatt1, Ha Sirtlan Av1 (Pipeline or Hunting Hyena),” Milliyet, (January 3): 15.

Emirlioğlu, S. (1997). “Eller Tetiğe Uzanıyor (Hands are Moving to the Trigger)," Milliyet, (November 15): 21

Eralp, Y. (2001). "Kral Çıplak: Ermenistan Açılımı (The Naked King: Armenia Opening)," Milliyet, (February 19): 22.

Erdoğan, R.T. (2005). “Suriye’yi Satt1: Erdoğan Suriye'yi Satt1 (Syria Sold off: Erdoğan sold Syria),” Evrensel, (June 12).

Grabbe, H. (2001). "How Does Europeanization Affect CEE Governance? Conditionality, Diffusion and Diversity," Journal of European Public Policy, 8(6): 1013-1031.

------, (2003). "Europeanization Goes East: Power and Uncertainty in the EU Accession Process," in K. Featherstone, and C.M. Radaelli (eds.), The Politics of Europeanization: 303-330. Oxford; New York: Oxford University Press.

Güven, B. (1996). “Iran’a Kuzey Irak’ta Arabuluculuk Teklifi (Mediation Offer to Iran in Northern Iraq)," Milliyet, (October 23): 18. 
Herrberg, A. (2008) Perceptions of International Peace Mediation in the EU: A Need Analysis. Initiative for Peace Building. Available [online] at:

http://www.initiativeforpeacebuilding.eu/pdf/Needs_analysis.pdf

Héritier, A. and Knill, C. (2001). "Differential Responses to European Policies: A Comparison," in A. Héritier (ed.), Differential Europe: The European Union Impact on National Policymaking: 257-294. MD: Rowman and Littlefield.

Hughes, J.R., Sasse, G., and Gordon, C. (2004). "Conditionality and Compliance in the EU's Eastward Enlargement: Regional Policy and the Reform of Sub-National Government," Journal of Common Market Studies, 42(3): 523-551.

İdiz, S. (2005). “İsrail’ in Ankara Büyükelçisi: Bizimki Aile İçi Kavga (Israel’s Ambassador to Ankara: Ours is a Family Fight)," Milliyet, (May 1).

Kelley, J.G. (2006). "New Wine in Old Wineskins: Promoting Political Reforms through the New European Neighborhood Policy," Journal of Common Market Studies, 44(1): 29-55.

Kohen, S. (1995a). "Yorum: Türkiye de Bosna için Devrede (Turkey also Stepped in for Bosnia)," Milliyet, (May 20): 16.

------, (1995b). "Yorum: Türkiye (Daha) Ne Yapabilir? (What (Else) can Turkey Do?)," Milliyet, (June 1): 16.

-----, (1996). "Yorum: Talabani İlerliyor, Taliban Geriliyor (Talabani is Progressing, Taliban is Stepping Back)," Milliyet, (November 17): 18.

------, (1998). “Cem, Bağdat'a 'Kapsamlı Öneriler' Götürecek (Cem is Going to Bring 'Comprehensive Suggestions' to Baghdad)," Milliyet, (February 3): 20.

------, (2000). "Yorum: Türkiye Devreye Girerken (While Turkey is Being Involved)," Milliyet, (August 8): 17.

------, (2011). “Arabuluculuk Vizyonu (Mediation Vision),” Milliyet, (March 13).

March, J.G. and Olsen, J.P. (1989). Rediscovering Institutions: The Organizational Basis of Politics. New York: Free Press.

Miall, H. (1992). The Peacemakers: Peaceful Settlement of Disputes since 1945. Basingstoke: Macmillan.

Öke, M.K. (2004). "Şarm El Şeyh Toplantısı (Sharm El-Sheik Meeting)," Halka ve Olaylara Tercüman, (November 23).

Önal, A. (2005, 06 02). "Hükümetteyiz ama İktidar Değiliz (We are in Government, But We are not Government)," Akşam, (June 2). 
Özkaya, Y. (1993). “İsrail de Orta Asya'da İşbirliği için Türkiye’ye Yanaşıyor (Israel is also Approaching Turkey for Cooperation in Central Asia)," Milliyet, (March 27): 7.

Payzın, Ş. (2000). “Ankara'nın Önerisini Dikkate Alırız (We will Take Ankara's Proposal into Consideration)," Milliyet; (December 12): 27.

Radaelli, C.M. (2000). "Policy Transfer in the European Union,” Governance, 13(1): 25-43.

Report. (1995). "Demirel'in Bosna'ya Cuma Çıkarması (Demirel's Friday Appearance in Bosnia)," Milliyet, (July 21): 17.

------, (1997). “Türkiye Afganistan'da Arabulucu Oluyor (Turkey is Becoming a Mediator in Afghanistan)," Milliyet, (August 10): 19.

-----, (1998). “Meclis’te Gerginlik (Tension in the Assembly)," Milliyet, (February 3): 16.

-----, (2000a). “İsrail: Siz Bu İşe Karşımayın (Israel: Don’t You Get Involved),” Milliyet, (August 6): 22.

-----, (2000b). “Demirel için Telefon Zinciri (Telephone Chain for Demirel)," Milliyet, (November 2): 1 .

------, (2000c). “Türkiye’ye Yeni Rol (New Role to Turkey),” Milliyet, (November 28): 25.

------, (2003). "Krizsavar Gül: Türkiye, ABD için Arabulucu (Anti-Crises Gül: Turkey is the Mediator for the U.S.A)," Halka ve Olaylara Tercüman, (April 7).

------, (2003b). “Türkiye Arabulucu Olsun (Turkey Should be Mediator),” Cumhuriyet, (July 9).

------, (2004a). “Çıksa da Kurtulsak: AB’nin Kapısını Kırana Kadar Çalarız (We will Ring Europe’s Doorbell until We Break It)," Sabah, (May 20).21).

------, (2005a). “Ortadoğu'da Barış için Filistin'e Kırmızı Hat (Hotline to Palestine for Peace in the Middle East)," Hürriyet, (May 3).

-----, (2005b). “Türkiye'yi Ortadoğu'dan Dişlıyorlar (Turkey is Being Excluded from the Middle East)," Halka ve Olaylara Tercüman, (February 11).

------, (2005c). “Türkiye'nin Sınırı Yakında Açacağını Ümit Ediyoruz (We are Hoping that Turkey will Open the Border Soon)," Zaman, (February 25).

------, (2005d). “Diyalog Adımı Türkiye'de (A Dialogue Step in Turkey),” Radikal, (September 2).

Sarıkaya, M. (2006). “Rusya ve Iran (Russia and Iran),” Sabah, (January 3).

Sazak, D. (1994). "Siyaset Günlügüü Gürcistan Kapısı (Political Diary: The Georgian Gate)," Milliyet, (January 4): 18. 
Schimmelfennig, F. (2004). "The Impact of EU Democratic Conditionality in Central and Eastern Europe: A Qualitative Comparative Analysis." Paper presented at the Second Pan-European Conference, ECPR Standing Group on EU Politics, Bologna, (June).

Schimmelfennig, F. and Scholtz, H. (2008). "EU Democracy Promotion in the European Neighborhood: Political Conditionality, Economic Development and Transnational Exchange," European Union Politics, 9: 187-215.

Schimmelfennig, F. and Sedelmeier, U. (2004). "Governance by Conditionality: EU Rule Transfer to the Candidate Countries of Central and Eastern Europe," Journal of European Public Policy, 11(4): 661-679.

Schimmelfennig, F., Engert, S., and Knobel, S. (2003). "Costs, Commitment and Compliance: The Impact of EU Democratic Conditionality on Latvia, Slovakia and Turkey," Journal of Common Market Studies 41(3): 495-518.

Smith, K. (2003). "The Evolution and Application of EU Membership Conditionality," in M. Cremona (ed.), The Enlargement of the European Union: 105-139. Oxford; New York: Oxford University Press.

Touval, S. (2003). “Mediation and Foreign Policy,” International Studies Review, 5(4): 91-95.

Touval, S. and Zartman, I.W. (1985). International Mediation: Theory and Practice. Boulder, CO: Westview Press.

Vachudová, M. A. (2001). "The Leverage of International Institutions on Democratizing States: Eastern Europe and the European Union," RSCAS Working Papers (33).

Yalçın, N. (1988). “Dışişlerin’de Özal Kaygısı (MFA’s Özal Concern),” Milliyet, (December 30): 7.

Yavuz, T. (1987). “ABD Türkiye'den Rahatsız (The U.S. is Discontented with Turkey),” Milliyet, (October 24): 4.

Yazaroğlu, V. (1997). “Son Umudum Türkiye (Turkey is My Last Hope),” Milliyet, (January 10): 18.

Y1lmaz, Ö. (2000). "Ecevit Hindistan'da Arabulucu gibi (Ecevit is Like a Mediator in India)," Milliyet, (April 1): 13.

------, (2001). “Barışa Son Çağrı (Final Call for Peace),” Milliyet, (July 23): 14.

Y1lmaz, Ö. and Yazaroğlu, V. (1998). “Türkiye Barışa Arabulucu (Turkey is Mediator for Peace),” Milliyet, (September 9): 19.

Yinanç, B. (1994) “Hırvatlar' dan Övgü (Praise from Croatians),” Milliyet, (March 3): 22.

-----, (1996). “Çiller Arabuluculuk Önerdi (Çiller Offered Mediation),” Milliyet, (October 1): 19. 
------, (2000a). “Türkiye, İsrail’i de Dinledi (Turkey Listened to Israel as well),” Milliyet, (August 11): 26.

------, (2000b). “Cem'den Arafat'a: Devlet İlanı Barışa Köstek Olur (From Cem to Arafat: Declaration of Independence would be Detrimental to Peace)," Milliyet, (August 25): 17. 